INTERNATIONAL JOURNAL OF RESEARCHES IN BIOSCIENCES, AGRICULTURE AND TECHNOLOGY

(C) VISHWASHANTI MULTIPURPOSE SOCIETY (Global Peace Multipurpose Society) R. No. MH-659/13(N)

www.ijrbat.in

\title{
INDUCTION OF CALLUS FROM LEAF EXPLANT BY USING AUXINS IN DESMODIUM GANGETICUM (L.) DC
}

\author{
V. N. Patil ${ }^{1}$ and S. S. Deokule ${ }^{2}$ \\ 1. Department of Botany, Vidyabharati College, Seloo, Dist. Wardha-442104, Maharashtra. \\ 2. Department of Botany, SavitribaiPhule University of Pune, Pune - 411 007, Maharashtra.
}

Email: vnpati185@gmail.com

\begin{abstract}
:
Desmodium gangeticum (L.) DC is an important medicinal plant belongs to family Fabaceae (Leguminoceae). It is known as Salparni in Sanskrit. It is a sub-erect, under-shrub 0.6-1.2m high with irregular angled, branched woody stem. Leaves are unifoliate or trifoliate. Flowers are small, pink to purple in color. Whole plant or mainly the roots are used in medicines. It is used in Ayurvedic preparations like Dashmoola-Kwatha and Dashamoola-rishta. In the present investigation, an efficient protocol for callus induction of $D$. gangeticum is developed from the leaf. The leaf explant was inoculated with basal cut surface down on Murashige and Skoog medium supplemented with $0.25,0.5,0.75,1 \mathrm{mg} / 1$ IAA, NAA and 2,4- D for callus induction. The better and profuse callus induction was found in MS medium supplemented with $0.5 \mathrm{mg} / 12$, $4 \mathrm{D}$ from the leaf explants.
\end{abstract}

Keywords: Desmodium gangeticum, Callus induction, Explants.

\section{INTRODUCTION:}

Desmodium gangeticum (L.) DC belongs to family Fabaceae (Leguminoceae). It is known as Salparni in Sanskrit. It is a sub-erect, under-shrub $0.6-1.2 \mathrm{~m}$ high with irregular angled, branched woody stem. Leaves are unifoliate or trifoliate. Flowers are small, pink to purple in color (Chopra et al., 1956). It is found in India, China, Africa, Australia, Ceylon, Burma, Malay Peninsula, Islands, Philippines and Tropical Africa (Anonymous, 1952; Cook, 1967; Hooker, 1973). Whole plant or mainly the roots are used in medicines. In Ayurveda, it is used to treat the various conditions such as snakebite, ulcer and diabetes (Anonymous, 1952; Cook, 1967; Hooker, 1973), in asthma, bronchitis, dysentery, fever (Dharmani and Palit, 2006), in heart diseases (Kirtikar and Basu, 1935). It is used in Ayurvedic preparations like Dashmoola-Kwatha and Dashamoola-rishta (Kirtikar and Basu, 1935; Chopra et al., 1956). In the Ayurvedic system of medicines, it is used as an analgesic, antiarthritis, against cough, rheumatism, astringent, in diarrhea, tonic, diuretic, fever, biliousness, cough, vomiting, asthma, snake-bite, scorpion- sting (Anonymous, 1992).

The drug $D$. gangeticum is mostly collected from wild sources to meet the requirement of pharmaceutical industries. Department of Indian Systems of Medicine and Homeopathy, Ministry of Health and Family Welfare, Government of India has formulated a Central Scheme for Cultivation and Development of Medicinal Plants. D. gangeticum is one of the species identified for promoting the cultivation in order to reduce the pressure on natural habitat and to meet the shortage against the demand of the industry (Rawat and Sharma, 1998). It is identified as a promising plant which is in great demand and of a high commercial potential. An estimated domestic demand for D. gangeticum is about 678.4 tones/year (Anonymous, 2001). In vitro plant regeneration from various explants has been reported in D. gangeticum (Patil and Deokule, 2012, 2014, 2016) as well as callus induction from stem explant (Patil and Deokule, 2017). But there is no report on callus induction from leaf explant. Due to its highly potential applications and chemical properties also present in the leaf and during the cutting of stem it will directly affects on the plants. Hence, it is essential to study the plant for future benefits to meet basic needs of chemical constituents without disturbing its life cycle. Hence, in the present study, the callus inductions have been studied from the leaf explant supplemented with the various concentrations of auxins in MS medium.

\section{METHOD AND MATERIAL:}

Collection and Identification of Plant Material:

The plant material was collected from Western Ghats of Maharashtra, India. Efforts were made to collect the plant material in flowering and fruiting condition for the correct botanical identification and authentication. It was identified with help of Flora of Presidency of Bombay (Cook, 1967). Herbarium specimens were prepared and it was authenticated 
from Botanical survey of India, Pune. The voucher specimen number is BSI/WRC/Tech/2011/PAVNDGI.

\section{Preparation and Sterilization of Seeds}

The fresh mature legumes of $D$. gangeticum were harvested for the germination. The outer covering of the legumes were removed by hand and keep in dark. The fresh mature seeds were treated with concentrated $\mathrm{H}_{2} \mathrm{SO}_{4}$ for $10 \pm 1$ minute. Two washes were given with distilled water for 2 minutes (without sterilized). Then, the seeds were taken under aseptic condition and 2 washes given with sterilized distilled water for 2 minutes each which is followed by one wash of $0.1 \% \mathrm{HgCl}_{2}$ for 1 minute. The procedure terminated with the four washes of sterilized distilled water for 1 minute each. The seeds are then transferred on $1 / 2 \mathrm{MS}$ medium containing water-agar $(0.6 \%)$ and incubated at 25 $28^{\circ} \mathrm{C}$ under $16 / 8$ hours photoperiod (Light/dark) of $20 \mu \mathrm{mol} \mathrm{m}-2 \mathrm{~s}-1$ irradiance provided by cool-white fluorescent tubes (Patil \& Deokule, 2014).

\section{Inoculation of Leaf Explant:}

The in vitro plant material were used after attaining the height about $15-20 \mathrm{~cm}$. The leaf explants were cut by scalpel. The explants were surface sterilized with $0.1 \% \mathrm{HgCl}_{2}$ for two minutes and then rinsed three times with the sterilized distilled water and inoculated on Murashige and Skoog's (MS) medium (Murashige and Skoog, 1962) supplemented with $0.25,0.5,0.75,1 \mathrm{mg} / 1$ IAA, NAA and 2,4- D for callus induction. The $\mathrm{pH}$ of the medium was adjusted to 5.8 with $0.1 \mathrm{~N} \mathrm{NaOH} \mathrm{/} \mathrm{HCl}$ before addition of $0.8 \%$ agar. Medium was autoclaved at $121^{\circ} \mathrm{C}$ at $151 \mathrm{bs}$ for $20 \mathrm{~min}$. The cultures were incubated at $25 \pm 2^{\circ} \mathrm{C}$ under photoperiod $16 / 8 \mathrm{hr}$ (light/dark). The light source used was cool white florescent tubes providing an illumination of 2000/lux /m2 /s. The explants were cultured under laminar air flow chamber. After four weeks, the data were recorded and were sub-cultured on the new medium of same concentrations.

\section{Growth kinetics of callus:}

After four weeks of incubation, the calli obtained on all the culture treatments were harvested. Fresh weight was taken and then the calluses were dried in oven at $60^{\circ} \mathrm{C}$ until constant weight was obtained (Sestak, et al., 1971). The growth of callus was determined on the basis of dry weight. The proliferation of callus on MS media fortified with BA in combination with Auxins is also observed and noted it for further research/s.

\section{RESULT AND DISCUSSION:}

In order to induce the callus in $\mathrm{D}$. gangeticum, the leaf explant was cultured on MS medium containing different concentrations of NAA, IAA, 2,4-D (0.25, $0.5,0.75$ and $1 \mathrm{mg} /$ lit). After 28 days the calli were harvested and calculated the moisture content and dry weight of callus. In the present study, we have evaluated the effect of auxins (IAA, NAA and 2,4- D) on leaf explants. The results are presented in (Table 1 and Figures). All the hormonal concentrations were found to be responsible for the development of callus except the control from the leaf explant, the $0.5 \mathrm{mg} / 12,4-\mathrm{D}, 0.5 \mathrm{mg} / 1 \mathrm{IAA}$ and $0.75 \mathrm{mg} / 1 \mathrm{NAA}$ in MS medium were found to be the best hormone concentrations used for profuse callus induction among all the concentration. Moreover, the size and physical appearance of the calli formed on various concentrations of the same auxins did not show any difference except the color. As the concentrations of the auxins were increased, the size and appearance of the calli were found to be decreased. This is the first report of such induction of callus in various concentrations of auxins.

The callus derived from the leaf explant showing the remarkable responses on MS media fortified with BA in combination with Auxins. The control does not develop the callus. In lower concentration of BA $(0.25 \mathrm{mg} / 1)$ in combination with increased level of $0.5 \mathrm{mg} / 1$ IAA showing callus proliferation but as decreasing the concentration the callus fails to survive. In case of BA in combination with NAA showing better response and healthy proliferation callus. If 2, 4-D concentration will increased the callus does not showing more response for the proliferation of callus. In higher concentration of BA $(0.5 \mathrm{mg} / 1)$ in combination with increased level of $0.5 \mathrm{mg} / 1$ IAA showing good callus proliferation as compare to decreasing the concentration of IAA $(0.25 \mathrm{mg} / 1)$. In case of $0.5 \mathrm{mg} / 1 \mathrm{BA}$ in combination with increased level of NAA $(0.75 \mathrm{mg} / 1)$ showing good response and better proliferation callus. If 2,4-D concentration will increased the callus does not showing more response for the proliferation of callus (Table 2 and Figures).

Yellowish white and greenish white friable calli were developed from the leaf explant in various concentrations of auxins. But the greenish white is found to be better calli for the fast growing, friable callus. Callus initiation was observed within 8 days and induction within 28 days. Leaf explant was showing early and profuse callus induction in MS medium in combination with BA supplemented 
with $0.5 \mathrm{mg} / 12$, $4-\mathrm{D}, 0.5 \mathrm{mg} / 1$ IAA and $0.75 \mathrm{mg} / 1$ NAA where as stem explant showing such type of callus formation in MS medium supplemented with $0.75 \mathrm{mg} / 1$ IAA, 0.75NAA \& 0.5mg/1 2,4-D (Patil \& Deokule, 2017). Babu et al. (1992) reported callus formation from the young leaves of $Z$. Officinale cultured on MS medium containing 2-5 mg/1 2,4-D. Hamideh et al. (2012) reported the callus induction from leaf explant in medium containing of 2,4-D in combination with BA were better in Falcaria vulgaris. As we go to higher and lower hormone concentration to get optimum response of callus. Callus cultures are extremely important in plant biotechnology. Finally, the protocol of efficient callus induction from leaf explant is selected in MS medium supplemented $0.5 \mathrm{mg} / 12$, 4-D, $0.5 \mathrm{mg} / 1$ IAA and $0.75 \mathrm{mg} / 1 \mathrm{NAA}$ for biotechnological appliances.

\section{REFERANCE :}

Anonymous (1952) : The Wealth of India (Raw materials); CSIR New Delhi D-E : 41-43.

Anonymous (1992) : Preparation of kwath and Dashmulakwath in Bangladesh National Formulary of Ayurvedic Medicine, Approved by the Govt. of Bangladesh vide Ministry of Health and Family Welfare, Memo No. Health1/Unani-2/89 I., 20-32, 116.

Anonymous (2001) : Agenda for the meeting of medicinal plants board; (Annexure), Dept. of ISM \& $\mathrm{H}$, Ministry of Health and Family Welfare, Govt. of India, New Delhi, 2 : 910, 38, 44, 48-50, 55, 65.

Babu, K.N., Samsudeenn, K. and Ratnambal, M.J. (1992).In vitro plant regeneration from leafderived callus in ginger.Plant Cell, Tissue Culture, 29: 71-74.

Chopra, R.N., Nayar, S.L. and Chopra, I.C. (1956) : Glossary of Indian Medicinal Plants. Council of Scientific and Industrial Research, New Delhi :94.

Cook, T. (1967) : The Flora of Presidency of Bombay, Botanical Survey of India, Calcutta, 13: 379-380.

Dharmani, P. and Palit, G. (2006) : Exploring Indian medicinal plants for antiulcer activity. Indian $\mathrm{J}$ Pharmacol, 38 (2): 95-99.

Dharmani. P., Mishra, P.K., Maurya, R., Chauhan, V.S. and Palit, G. (2001)
:Desmodiumgangeticum: a potent anti-ulcer agent. Indian J ExpBiol, 43(6): 517-521.

Hamideh, J., Khosro, P. and Nazari, J. (2012). Callus induction and plant regeneration from leaf explants of Falcaria vulgaris an important medicinal plant. Journal of Medicinal Plants Research Vol. 6(18): 3407-3414.

Hooker, J.D. (1973) Flora of British India; Reprinted edition, Periodical Experts, Delhi, 2 : 168.

Kirtikar, K.R. and Basu, B. D. (1935) : Indian Medicinal Plants; Vol.1 (Lalit Mohan Basu and Co., India, 204-212,758-760.

Murashige, Y. and Skoog, F.A. (1962) : Revised medium for rapid growth and bioassay with Tobacco tissue cultures, Physiol Plant,15: 473497.

Patil, V.N. and Deokule, S.S. (2012) : In-vitro seeds germination and plantlets development of $D$. gangeticum(L.) DC, International Journal of Current Research,4(8): 21-24.

Patil, V.N. and Deokule, S.S. (2014) :Rapid In vitro regeneration of Desmodium gangeticum(L) DC, Asiatic journal of biotechnology resources, 4(3):48-53.

Patil, V.N. and Deokule, S.S. (2016) :High frequency of multiple shoot induction in Desmodium gangeticum (L.) DC. byusing different concentrations of BAP, International Journal of Life sciences, A6: 101-104.

Patil, V.N. and Deokule, S.S. (2017) :Induction of Callus from stem explant by using Auxins in Desmodium gangeticum (L.) DC, International Journal of Research in Bioscience, Agriculture \& Technology, 2(V): 1029-1031.

Rawat, G.S. and Sharma, A.K. (1998) Stratrergies for the conservation medicinal plants in the Himalayas; In Prosects of Medicinal Plants, (Indian Society of Plant Genetic Resources, New Delhi, India, 29-36.

Sestak, A., Castky, J. and Jervis, P. (1971) methods of growth analysis. In W. Junk (eds.) plant photosynthetic production: manual of methods, NV publishers, The Hague: 363-443. 
TABLES:

Table 1: Influence of Auxins alone for the production of callus in leaf derived explant

\begin{tabular}{|c|c|c|c|c|}
\hline \multicolumn{3}{|c|}{ MS + PGR/s (mg/1) } & \multirow[t]{2}{*}{ Moisture \% } & \multirow[t]{2}{*}{ D. W. mg } \\
\hline IAA & NAA & $2,4-D$ & & \\
\hline \multicolumn{3}{|c|}{ Control } & - & - \\
\hline 0.25 & & & $88.9 \%$ & $154 \pm 1.6$ \\
\hline 0.5 & & & $94.6 \%$ & $153 \pm 1.2$ \\
\hline 0.75 & & & $92.7 \%$ & $61 \pm 1.4$ \\
\hline \multirow[t]{9}{*}{1} & & & $90.8 \%$ & $164 \pm 1.1$ \\
\hline & 0.25 & & $91.6 \%$ & $159 \pm 1.9$ \\
\hline & 0.5 & & $91.9 \%$ & $152 \pm 1.7$ \\
\hline & 0.75 & & $93.2 \%$ & $164 \pm 2.1$ \\
\hline & 1 & & $90.8 \%$ & $98 \pm 1.5$ \\
\hline & & 0.25 & $92.2 \%$ & $160 \pm 1.4$ \\
\hline & & 0.5 & $93.1 \%$ & $184 \pm 1.1$ \\
\hline & & 0.75 & $90.5 \%$ & $112 \pm 2.0$ \\
\hline & & 1 & $88.3 \%$ & $148 \pm 2.1$ \\
\hline
\end{tabular}

Table 2: Proliferation of callus on MS media fortified with BA in combination with Auxins.

\begin{tabular}{|c|c|c|c|c|c|}
\hline \multicolumn{4}{|c|}{ MS + PGRs (mg/1) } & \multicolumn{2}{|c|}{ Leaf derived callus } \\
\hline BA & IAA & NAA & 2,4-D & Callus response & Remark \\
\hline \multicolumn{4}{|c|}{ Control } & - & - \\
\hline \multirow{6}{*}{0.25} & 0.25 & & & ++ & Callus fail to survive \\
\hline & 0.5 & & & +++ & Callus proliferation \\
\hline & & 0.5 & & +++ & Callus proliferation \\
\hline & & 0.75 & & ++ & Callus proliferation \\
\hline & & & 0.25 & +++ & Callus proliferation \\
\hline & & & 0.5 & ++ & Callus fail to survive \\
\hline \multirow{6}{*}{0.5} & 0.25 & & & + & Callus proliferation \\
\hline & 0.5 & & & ++ & Callus proliferation \\
\hline & & 0.5 & & ++ & Callus proliferation \\
\hline & & 0.75 & & +++ & Callus proliferation \\
\hline & & & 0.25 & +++ & Callus proliferation \\
\hline & & & 0.5 & ++ & Callus fail to survive \\
\hline
\end{tabular}

Data scored after 4 weeks: Degree of callusing: - absent, + poor callus, ++ medium callus, +++ good callus, ++++ profuse callus, Nature of callus - friable yellowish white and greenish white in color.

\section{FIGURES:}
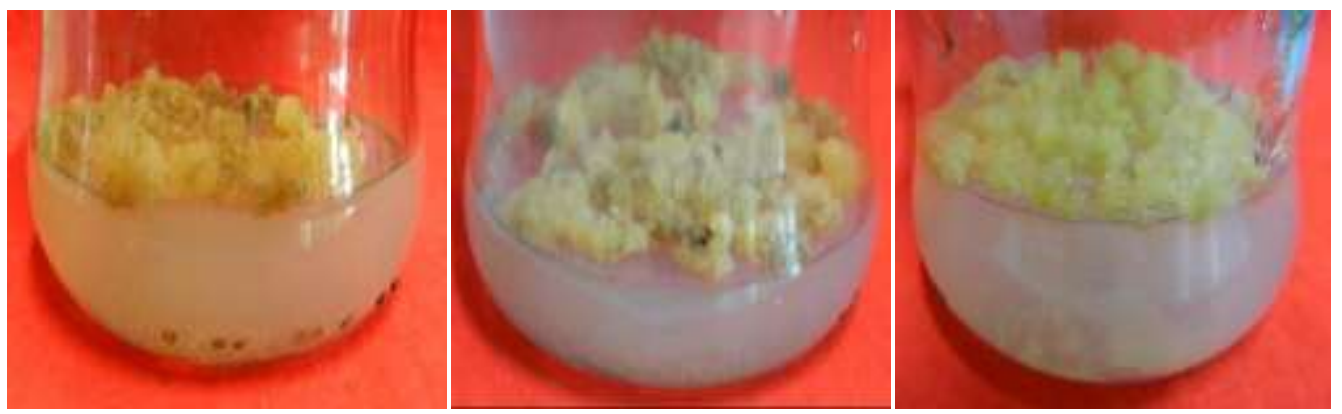

$0.75 \mathrm{mg} / 1 \mathrm{NAA}$

$0.5 \mathrm{mg} / 1$ IAA

$0.5 \mathrm{mg} / 12,4-\mathrm{D}$

Figure: Callus induction in various concentrations of auxins from leaf explant 